\title{
Changing populations of birds and mammals in North Sulawesi
}

\author{
Timothy G. O'Brien and Margaret F. Kinnaird
}

The issues of habitat loss and hunting are of paramount importance to wildlife conservation in Asia. In Sulawesi, Indonesia, these problems are having a serious impact on the vertebrate fauna. Using line-transect methods, the densities of 11 species of large birds and mammals were compared between 1979 and 1994 in the Tangkoko-DuaSudara Nature Reserve in North Sulawesi. During those 15 years, populations of anoa Bubalus depressicornis, bear cuscus Phalanger ursinus, crested black macaque Macaca nigra, maleo Macrocephalon maleo and red junglefowl Gallus gallus declined by 50-95 per cent while populations of Sulawesi pig Sus celebensis, Tabon scrubfowl Megapodius cumingii, Sulawesi tarictic hornbill Penelopides exarhatus and red-knobbed hornbill Aceros cassidix increased by 5-100 per cent. We considered hypotheses for these changes: habitat loss outside the reserve, habitat degradation inside the reserve, and hunting. Only hunting adequately explained the pattern of changing densities observed. Unless protection from hunting is enforced for these species, we may soon witness the demise of these unique animals in North Sulawesi and possibly throughout the island.

\section{Introduction}

Habitat loss, isolation and degradation are perhaps the most pernicious problems affecting wildlife populations around the world (Harris, 1984; Ehrlich, 1988). Land clearance for agriculture or timber adjacent to forests results in degraded habitats that are often abandoned and allowed to regenerate, creating secondary forest, scrub or grasslands. The value of these degraded lands to forest wildlife is variable; some forest species may use them, others may not. Associated with these anthropogenic habitat disturbances are additional pressures on wildlife. Commercial and subsistence hunting (Redford and Robinson, 1985; Redford, 1992; Srikosamatara et al., 1992) as well as agricultural-pest control place many wildlife species at risk.

The Indonesian island of Sulawesi provides a perfect case study of the effects of habitat loss, degradation and forest isolation on wildlife communities. Over the last two decades Sulawesi has lost over 67 per cent of productive wet lowland forest habitat (Whitten et al., 1987). Although commercial logging for export ceased to be important by 1981, logging for commercial and local use has continued and directly threatens endemic species such as the anoa Bubalus depressicornis and babirusa Babyrousa babirussa. Land clearance for agriculture has converted additional forest land on slopes too steep for logging (Whitten et al., 1987).

Hunting of wildlife for commercial markets and personal consumption is common among the Christian people of North Sulawesi and bush meat is commonly available in the markets. The price of bush meat, moreover, is comparable to that of domestic meat, suggesting that bush meat is neither especially valued nor more economical than domestic meat.

The Tangkoko-DuaSudara Nature Reserve (Tangkoko) of North Sulawesi was formerly the core of a much larger, contiguous forest block that included the Wiau Protection Forest 
with corridors to the nearby Mt Klabat forest (MacKinnon and MacKinnon, 1981). In the late 1970s, K. and J. MacKinnon conducted surveys of large birds and mammals and concluded that the density of large vertebrates was higher in Tangkoko than in any other area in Indonesia. They rated Tangkoko as the most important conservation area in Sulawesi and an extremely valuable area for the maintenance of biodiversity in Indonesia.

Today, much of the Wiau Protection Forest has been converted to coconut farms and $\mathrm{Mt}$ Klabat forest has been reduced to a remnant at the top of the mountain. Tangkoko is effectively isolated and the entire forest complex has been reduced to less than half its original extent. The combination of habitat loss, hunting and previous census data provided an opportunity to assess the impact of human disturbance over a defined time period. In this paper we discuss changes over 15 years in population densities of selected large birds and mammals of Tangkoko in response to these pressures.

\section{Sulawesi}

Sulawesi is the largest and most central island of Wallacea, the biogeographical transition zone between the Asian region to the west and the Australasian region to the east. Sulawesi's fauna has a high degree of endemism: 34 per cent of the bird species and 98 per cent of nonvolant mammals are endemic (Whitten et al., 1987). These include endangered species such as the maleo Macrocephalon maleo, a bird that incubates its eggs in volcanic sands, the babirusa or pig deer, and the anoa, a dwarf buffalo. The diversity of macaques Macaca spp. is unrivalled elsewhere in Asia. In spite of its interesting biogeographical position, little has been written about the natural history of this important island and most of its endemic fauna.

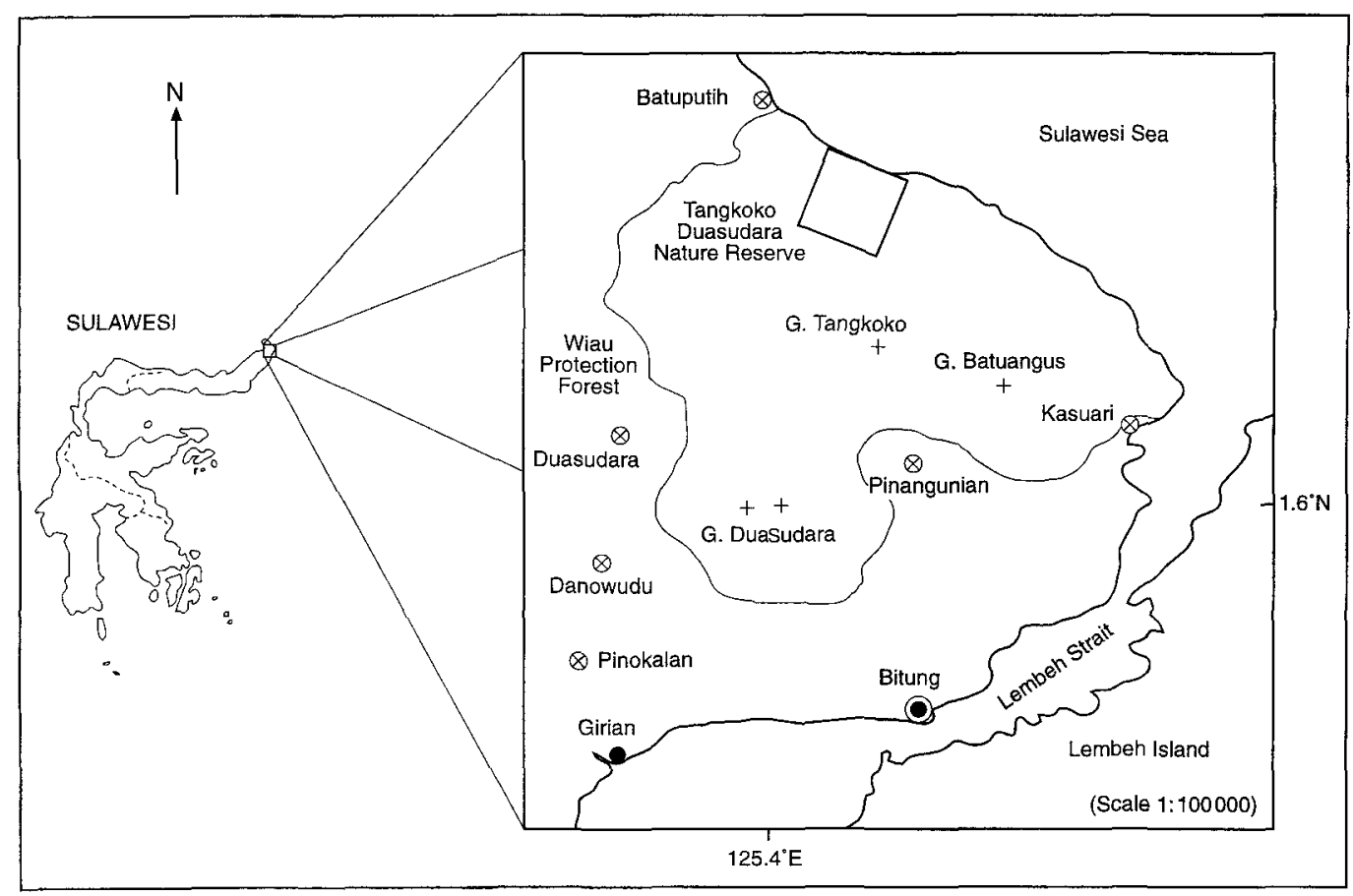

Figure 1. Map of Tangkoko-DuaSudara Nature Reserve in Sulawesi, Indonesia. 


\section{Tangkoko-DuaSudara Nature Reserve}

The Tangkoko-DuaSudara Nature Reserve lies at the northernmost tip of Sulawesi $\left(1^{\circ} 34^{\prime} \mathrm{N}\right.$, $125^{\circ} 14^{\prime} \mathrm{E}$; Figure 1). Tangkoko was first established as a forest reserve by the Dutch colonial government in 1919 and was retained in the nature reserve system after Indonesia gained independence. The reserve covers 8867 ha and its altitude ranges from sea level to $1350 \mathrm{~m}$. There are three volcanoes in the reserve; a tuft cone $(450 \mathrm{~m})$ that resulted from an eruption in 1839, Mt Tangkoko $(1100 \mathrm{~m})$ and the twin peaks of DuaSudara $(1351 \mathrm{~m})$. The reserve has several villages on its borders, inhabited by people who cultivate coconut and other crops and hunt within the reserve.

A special feature of the reserve is the broad range of habitats within a relatively small area. There are seven recognized vegetation communities (MacKinnon and MacKinnon, 1981) including fire-maintained Imperata grasslands, early secondary forest on old farm sites, Casuarina forest, beach forest, lowland rain forest, submontane forest and elfin moss forest. Recent fires and extensive treefalls result in a complex mosaic of successional stages of forest communities, all within $6 \mathrm{~km}$, from the ocean to the volcano summits (M.F. Kinnaird and T. G. O'Brien, unpubl. data).

\section{Methods}

Data were collected on 11 species of birds and mammals (Table 1) from April 1993 to March 1994, using line transects (Burnham et al., 1980) for estimating wildlife densities. Each month, two observers walked four transects, once in the morning and once in the afternoon. Transect lengths ranged from 4.65 to 5.9 $\mathrm{km}$ and the total length of transects walked was $42 \mathrm{~km}$ per month. For each animal or group of animals encountered records were made of the numbers observed, their perpendicular distance from the transect, time and elevation.

Population densities for the north slope of the reserve were estimated using three different line-transect estimation techniques, depending on the quality of data available for a species. The DISTANCE program (Laake et al., 1993) was used to make monthly, variablewidth transect estimates for common species (encountered more than 20 times a month on average). Monthly fixed-width transect estimates were made for rare species (encountered fewer than 20 times a month). Finally, single, fixed-width estimates were made for the rarest species (observed fewer than 20 times a year). Monthly estimates were averaged for overall density estimates.

\begin{tabular}{llll}
\hline English name & Scientific name & Endemic & Hunted \\
\hline Anoa & Bubalus depressicornis & $\mathrm{Y}$ & $\mathrm{Y}$ \\
Sulawesi pig & Sus celebensis & $\mathrm{Y}$ & $\mathrm{Y}$ \\
Javan rusa & Cerous timorensis & $\mathrm{N}$ & $\mathrm{Y}$ \\
Crested black macaque & Macaca nigra & $\mathrm{Y}$ & $\mathrm{Y}$ \\
Bear cuscus & Phalanger ursinus & $\mathrm{N}$ & $\mathrm{Y}$ \\
Babirusa* & Babyrousa babirussa & $\mathrm{Y}$ & $\mathrm{Y}$ \\
Maleo & Macrocephalon maleo & $\mathrm{Y}$ & Eggs \\
Tabon scrubfowl & Megapodius cumingii & $\mathrm{N}$ & Eggs \\
Red junglefowl & Gallus gallus & $\mathrm{N}$ & $\mathrm{Y}$ \\
Red-knobbed hornbill & Aceros cassidix & $\mathrm{Y}$ & $\mathrm{Y}$ \\
Sulawesi tarictic hornbill & Penelopides exarhatus & $\mathrm{Y}$ & $\mathrm{N}$ \\
\hline
\end{tabular}

${ }^{*}$ MacKinnon and MacKinnon (1981) unsure of presence in reserve. $\mathrm{N}$, not endemic; $\mathrm{Y}$, exploited.
Table 1. Selected large mammals and birds of TangkokoDuaSudara Nature Reserve, showing which are endemic and which are exploited by humans 


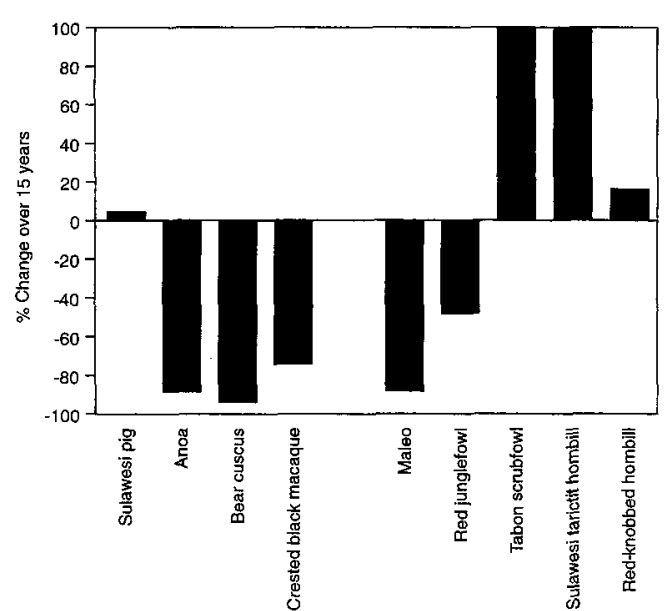

Figure 2. Percentage change in population density of selected large bird and mammal species in Tangkoko over 15 years (1979-94).

Our density estimates were compared with data reported by the MacKinnons in 1978/79. They conducted fixed-width line transect surveys each month for 15 months. We used a subset of the MacKinnon trails and also used observers that were trained by the MacKinnons in census work. It can be assumed, therefore, that methodological biases are minimal for the two data sets, except for intensity of effort. Density estimates generated by DISTANCE may be higher than fixedwidth estimates for the same data. Comparisons between our DISTANCE estimates and MacKinnons', therefore, may be somewhat conservative for declining populations. Differences in density estimates between 1978 and 1994 are assumed to reflect real changes in animal populations.

\section{Results and discussion}

Changes in population density over 15 years were variable for the 11 species examined (Table 2; Figure 2). In general, mammal populations experienced the most dramatic changes in population densities; with the exception of the Sulawesi pig, none of the mammals have maintained former densities. Bird populations fared better: two populations declined but three increased.

We did not encounter Javan rusa or babirusa during our surveys (Table 2). Although rusa are observed infrequently in the study area, they occur at extremely low densities. The status of the babirusa was in doubt in the 1970s when one animal was released into the reserve (MacKinnon and MacKinnon, 1981); our data indicate that it has been extirpated from Tangkoko. The anoa population has declined by 90 per cent and appears to be on the verge of local extinction.

The decline of the crested black macaque population was first reported in 1989 (Sugardjito et al., 1989) and our figures indicate a continuing decline. The MacKinnons estimated the crested black macaque population in Tangkoko at around 15,000 individuals; today we estimate 3100 . Given current trends, the crested black macaque population may disappear from Tangkoko in 25-100 years.
Table 2. The results of surveys of selected large vertebrates in Tangkoko DuaSudara Nature Reserve in 1993/94

\begin{tabular}{lllc}
\hline Species & $\begin{array}{l}\text { Line transect } \\
\text { model }\end{array}$ & $\begin{array}{l}\text { Estimated } \\
\text { density } \\
\text { (per sq km) }\end{array}$ & SE \\
\hline Anoa & Year/Fixed & 0.05 & - \\
Sulawesi pig & DISTANCE & 12.0 & 7.4 \\
Crested black macaque & Fixed & 58.0 & 16.5 \\
Bear cuscus & Year/Fixed & 2.0 & - \\
Babirusa & None & - & - \\
Maleo & Year/Fixed & 0.2 & - \\
Tabon scrubfowl & DISTANCE & 6.2 & 1.2 \\
Red junglefowl & DISTANCE & 1.5 & 0.3 \\
Red-knobbed hornbill & DISTANCE & 67.3 & 17.7 \\
Sulawesi tarictic hornbill & Fixed & 2.8 & 0.1 \\
\hline
\end{tabular}


Among the ground-nesting birds, the maleo population is on the verge of extinction; we estimate only seven pairs left in the reserve. Red junglefowl have declined but not as dramatically as the maleo. These numbers are in contrast with those of the Tabon scrubfowl, another megapode, whose numbers have doubled in 15 years. Population densities of the canopy-dwelling Sulawesi tarictic hornbill and red-knobbed hornbill have both increased. Whereas the tarictic hornbill is still considered to be rare ( $O^{\prime}$ Brien and Kinnaird, 1994), the red-knobbed hornbill densities are the highest recorded for any Asian forest hornbill (Kinnaird and $\mathrm{O}^{\prime}$ Brien, in press).

In order to investigate the factors that could cause major population declines over a large component of the vertebrate community in a relatively short time, we examined three hypotheses that might account for the pattern of species densities today compared with 15 years ago; loss of habitat around the reserve, loss and degradation of forest within the reserve, and over-hunting (Table 3 ).

Destruction of the protection forest adjacent to Tangkoko has been ongoing for at least 10 years. In the past 3 years, we have witnessed large blocks of forest converted to coconut plantations. The expected effect on wildlife populations would be an initial increase in population density within the reserve as wildlife is compressed into the remaining habitat. For a community of relatively long- lived species in the early stages of habitat compression, initial increases in density would be followed by relaxation back to carrying capacity, or fluctuations about the carrying capacity as populations settle to some equilibrium. We expect, on average, that population densities would be similar to, or higher than, densities recorded by MacKinnon and MacKinnon, whose research was conducted prior to habitat loss.

The expectation of general population density increases is not borne out by the data. Most species have declined in density and only the hombills, Tabon scrubfowl and Sulawesi pig exhibit population density stability or increases consistent with this hypothesis. Species that might best tolerate crowding would be those that include browse and leaves in their diet, for example the anoa and cuscus. These species declined. It therefore seems unlikely that habitat compression is the primary agent of the observed changes.

The second potential factor causing population changes is degradation of forests within the reserve. Over the past 15 years, habitat has been lost or altered due to fire and conversion of land to agriculture. Populations of species capable of exploiting early successional habitats and agricultural lands might be expected to increase in density, while those of primary forest specialists would be expected to decline. Crested black macaques, Sulawesi pigs, bear cuscus, Tabon scrubfowl, anoa and rusa all

\begin{tabular}{|c|c|c|c|c|}
\hline \multirow[b]{3}{*}{ Species } & \multirow{3}{*}{$\begin{array}{l}\text { Observed } \\
\text { change }\end{array}$} & \multicolumn{3}{|c|}{ Expected response to: } \\
\hline & & \multicolumn{2}{|c|}{ Habitat loss } & \multirow[b]{2}{*}{ Hunting } \\
\hline & & Outside & Inside & \\
\hline Anoa & $\mathrm{D}$ & $\mathrm{N} / \mathrm{I}$ & $\mathbf{N}$ & $\mathrm{D}$ \\
\hline Sulawesi pig & $\mathrm{N}$ & $\mathrm{N} / \mathrm{I}$ & $\mathrm{N}$ & $\mathrm{N} / \mathrm{D}$ \\
\hline Crested black macaque & $\mathrm{D}$ & $\mathrm{N} / \mathrm{I}$ & $\mathrm{N}$ & $\mathrm{D}$ \\
\hline Bear cuscus & $\mathrm{D}$ & $N / I$ & $\mathrm{D}$ & $\mathbf{D}$ \\
\hline Babirusa & $\mathrm{D}$ & I & $\mathrm{N}$ & $\mathrm{D}$ \\
\hline Maleo & $\mathrm{D}$ & $\mathrm{N}$ & $\mathrm{N}$ & $\mathrm{D}$ \\
\hline Tabon scrubfowl & $\mathrm{I}$ & $\mathrm{N} / \mathrm{I}$ & $\mathrm{N}$ & $\mathrm{N}$ \\
\hline Red junglefowl & $\mathrm{D}$ & $\mathrm{N} / \mathrm{I}$ & $\mathrm{D}$ & $\mathrm{N} / \mathrm{D}$ \\
\hline Red-knobbed hornbill & $\mathrm{I}$ & $\mathrm{N} / \mathrm{I}$ & $\mathrm{D}$ & $\mathrm{D}$ \\
\hline Sulawesi tarictic hornbill & $\mathrm{I}$ & $\mathrm{N} / \mathrm{I}$ & $\mathrm{D}$ & $\mathrm{D}$ \\
\hline
\end{tabular}

Table 3. Observed changes in population densities of selected vertebrate species and expected responses of wildlife populations within Tangkoko to habitat loss outside the reserve, to habitat loss inside the reserve, and to hunting

$D$, decline; $I$, increase; $N$, no change. 
use secondary habitat to some degree, while the maleo, Sulawesi tarictic hornbill and redknobbed hornbills are primary forest specialists (Kinnaird and $O^{\prime} B r i e n$, in press). Again, patterns of population increase and decline are inconsistent with expectation of population changes in response to loss and degradation of habitat within the reserve.

We believe that the observed density patterns reflect the consequence of excessive hunting and the differing ability of species to reproduce quickly enough to compensate for intense harvesting. Among the mammals, the crested black macaque, the bear cuscus and the anoa are in serious decline. Only the highly fecund Sulawesi pigs with litter sizes of eight or more are withstanding the harvest pressure.

The endemic hornbills, although exhibiting low reproductive rates (Kinnaird and $\mathrm{O}^{\prime} B$ rien, 1993; O'Brien and Kinnaird, in press), are less vulnerable because of hunting techniques. Most local hunting is carried out using traps, snares, air-powered pellet rifles and dogs. These hunting methods are useful for hunting terrestrial animals primarily; even pellet rifles seldom bring down the canopy-dwelling hornbills. For the megapodes, egg-collecting rather than direct trapping is the most serious threat. Megapodes are known throughout South East Asia and the South Pacific for their large eggs and unusual incubation habits (Whitten et al., 1987). Maleo are communal nesters, congregating at specific nesting grounds where they incubate their eggs in thermal soils or hot beaches. Nesting grounds are limited in distribution and most are known to collectors, resulting in the present situation of over-harvesting throughout Sulawesi (M. Argeloo, pers. comm.). Although the Tabon scrubfowl also nests on beaches it prefers to nest in rotting treefalls throughout the forest. As a result, it is difficult to exploit scrubfowl nests efficiently. The increase in Tabon scrubfowl population density may have resulted from a reduction in feeding competition by large, ground-foraging junglefowl and maleos as well as its relative safety from human predators.

These results are similar to the findings for exploited wildlife populations in the Amazon and other parts of South America. Large primates and slowly reproducing ungulates (such as tapir Tapir indicus) disappear first (Robinson and Redford, 1991). Collared peccaries Tayassu tajacu, with high reproductive rates thrive, while the less fecund whitelipped peccary Tayassu pecari is hunted to local extinction. We consider the Sulawesi pig and babirusa as analogous to collared and whitelipped peccaries and the parallel is clear.

Collection of maleo eggs is analogous to the collection of sea-turtle eggs or swiftlet nests (Francis, 1987; MacKinnon and Phillipps, 1993). The restricted nesting sites allow efficient exploitation of nests, destroying the production of the next generation if not controlled. In Honduras, the exploitation of olive ridley turtles is so intense that virtually all eggs are harvested on some beaches (Lagueux, 1991). Tabon scrubfowl egg-collection is less systematic and may be comparable to collection of rhea eggs Rhea americana in the Beni, Bolivia (Stearman, 1992).

When humans first arrived in Sulawesi around 30,000 BP (Whitten et al., 1987), they found an island relatively free of large predators, but quickly filled this role themselves. The diet of Sulawesi's first inhabitants contained many of the species still hunted today. Wildlife populations that formerly sustained Sulawesi's people are now being driven into serious decline as a burgeoning human population places increased demands on forest habitats and wildlife populations. Many hunted species are officially protected by law, but the laws are seldom enforced (USAID, 1994). Unless the people of North Sulawesi modify their diet and decrease hunting pressure on wildlife we may witness the disappearance of Sulawesi's unique vertebrate fauna in the not-too-distant future.

\section{Acknowledgements}

This work was conducted under the auspices of the Wildlife Conservation Society in collaboration with the Indonesian Directorate General for Nature Preservation and Forest Protection (PHPA) and Puslitbang Biologi of the Indonesian Institute of Science (PB/LIPI). Funding was provided by the 
Wildlife Conservation Society, the National Geographic Society (grant no. 4912-92) and the Wenner-Gren Foundation for Anthropological Research (grant no. 5543). We thank Soetikno Wiryoatmodjo (PB/LIPI), Dedi Darnaedi (PB/LIPI) and Romon Palete (PHPA-North Sulawesi) for their kind help throughout our time in Indonesia. Farenheid Pontonudis, Aman Dorongi and Finche, PHPA guards, are thanked for assisting with data collection.

\section{References}

Burnham, K.P., Anderson, D.R. and Laake, J.L. 1980. Estimation of Density from Line Transect Sampling of Biological Populations. Wildlife Monographs.

Ehrlich, P. 1988. The loss of diversity: causes and consequences. In Biodiversity (eds E. O. Wilson and F. M. Peter), pp. 21-27. National Academy Press, Washington, DC.

Francis, C.M. 1987. The Management of Edible Birds' Nest Caves in Sabah. Report to the Wildlife Section, Sabah Forest Department, Kota Kinabalu, Malaysia.

Harris, L. 1984. The Fragmented Forest: Island Biogeography Theory and the Preservation of Biotic Diversity. University of Chicago Press, Chicago.

Kinnaird, M.F. and O'Brien, T.G. 1993. Preliminary observations on the breeding biology of the endemic Sulawesi red-knobbed hornbill Rhyticeros cassidix. Tropical Biodiversity, 1, 107-112.

Kinnaird, M.F. and $O^{\prime} B$ rien, T. G. In press. Variation in red-knobbed hornbill densities: resource tracking in space and time. Auk.

Laake, J.L., Buckland, S.T., Anderson, D.R. and Burnham, K.P. 1993. DISTANCE User's Guide v2.0). Colorado Co-operative Fish and Wildlife Research Unit, Colorado State University, Fort Collins, CO.

Lagueux, C.J. 1991. Economic analysis of sea turtle eggs in a coastal community on the Pacific coast of Honduras. In Neotropical Wildlife Use and Conservation (eds J.G. Robinson and K. H. Redford), pp. 136-144. University of Chicago Press, Chicago.

MacKinnon, J. and MacKinnon, K. 1981. Cagar Alam Gn. Tangkoko-DuaSaudara, Sulawesi Utara
Management Plan 1981-1986. Bogor, Indonesia.

MacKinnon, J. and Phillipps, K. 1993. A Field Guide to the Birds of Borneo, Sumatra, Java and Bali. Oxford University Press, Oxford.

O'Brien, T.G. and Kinnaird, M.F. 1994. Notes on the density and distribution of the endemic Sulawesi tarictic hornbill (Penelopides exarhatus) in the Tangkoko-Dua Saudara Nature Reserve, North Sulawesi. Tropical Biodiversity, 2, 252-260.

O'Brien, T.G. and Kinnaird, M.F. In press. Behavioural ecology of the Sulawesi tarictic hornbill during the breeding season. Ibis.

Redford, K.H. 1992. The empty forest. Bioscience, 42, 412-422.

Redford, K.H. and Robinson, J.G. 1985. Hunting by indigenous people and conservation of game species. Cultural Survival Quarterly, 9, 41-44.

Robinson, J.G. and Redford, K.H. (eds). 1991. Neotropical Wildlife Use and Conservation. University of Chicago Press, Chicago.

Srikosamatara, S., Siripholdej, B. and Suteethorn, V. 1992. Wildlife trade in Lao PDR and between Lao PDR and Thailand. Natural History Bulletin of Siam, 40, 1-47.

Stearman, A.M. 1992. Neotropical indigenous hunters and their neighbours: Siriono, Chimane and Yuqui hunting on the Bolivian frontier. In Conservation of Neotropical Forests: Working from Traditional Resource Use (eds K. H. Redford and C. Padoch), pp. 108-128. Columbia University Press, New York.

Sugardjito, J., Southwick, C.H., Supriatna, J., Kohlaas, A., Baker, S., Erwin, J., Froehlich, K. and Lerche, N. 1989. Population survey of macaques in Northern Sulawesi. American Journal of Primatology, 18, 285-310.

USAID. 1994. Policy towards Protected Areas in Indonesia: Final Report. Report No. 38, AID Contract No. 497-0362, Jakarta, Indonesia.

Whitten, A.J., Muslimin, M. and Henderson, G.S. 1987. The Ecology of Sulawesi. Gadjah Mada University Press, Yogyakarta, Indonesia.

Timothy G. O'Brien and Margaret F. Kinnaird, Wildlife Conservation Society, International Programs, 185th and Southern Blvd, Bronx, NY 10460, USA. 